\title{
Robert Hooke and his Contemporaries
}

" $\mathrm{D}^{\mathrm{F}}$ R. ROBERT HOOKE is generally allowed to have been one of the greatest promoters of Experimental Natural Knowledge, as well as Ornaments of the seventeenth century, so fruitful of great genius." With suchlike words Richard Waller begins his introduction to the "Posthumous Works", and the judgment still holds good. Nevertheless, our information as to Hooke's life and character has hitherto been comparatively meagre, for Ward's "Life", and most of what has besides been written of him, derives from Waller's account, and Waller apparently had little personal knowledge of Hooke or his intimates, since he states that his main authorities are Hooke's brief biographical notes and the "Journals" of the Royal Society. It is typical that Hooke is one of the few great men of science of whom no portrait is available-possibly the only one, for even of Cavendish we have the well-known sketch prefixed to George Wilson's "Life" and the "Scientific Papers". Hard judgments have been pronounced on him, without, perhaps, much trouble taken about that understanding which is said to lead to comprehensive pardon. The publication* of Hooke's diary for 1672-80, now in the possession of the Corporation of the City of London, at least affords us some direct evidence as to his character and mode of life.

This Diary covers the period of the "Cutlerian Lectures" and "Philosophical Collections". Hooke was thirty-seven years old when he started it, and had already published the "Micrographia" and made some of his most important improvements in instruments, including the first Gregorian telescope with a pierced objective mirror, but was still in his scientific prime. The diary consists of brief entries in staccato style, as can best be shown by a typical entry.

"Monday June 15th Rose at 4. Mr. Amhurst desired a meeting this day at 3 . Tryd helioscope by reflection. Hurt my eye much-prosecuted Hevelius. Was at Lord Mayors and coffee house with Sir Ch. Wren. Lord pleased with accounts. Oliver a Rascall. Dean of Paules angry. At Garaways. Met Mr. Amhurst, 1 Guinny. View in Fleet Street 10sh. At Mr. Tompions".

It might be thought that this kind of thing would soon pall, but one reader at least has found it fascinating. The "Cutlerian Lectures", the "Philo-

* The Diary of Robert Hooke, M.A., M.D., F.R.S., 1672-1680 Transcribed from the Original in the possession of the Corporation of the City of London (Guildhall Library). Edited by Henry W.
Robinson and Walter Adams. Pp. xxviii $+527+8$ plates. (London: Taylor and Francis, 1935.) 25s. sophical Collection", and Birch's "History of the Royal Society" go far to elucidate obscurities and amplify allusions, while the Diary makes the formal records extraordinarily vivid and personal.

For general interest this Diary does not, of course, challenge comparison with Pepys, but we must respectfully dissent from the judgment implied in the charming words of introduction by the honoured president of the Royal Society, Sir Frederick Gowland Hopkins, that the difference in style is partly attributable to the fact that Hooke's diary was meant for himself alone, while Pepys had his eye on eventual readers. Surely the fact that Pepys, who used a special secret shorthand, was essentially a gossip and a man about town, while Hooke was a man whose interests were concentrated on pure and applied science, and who had no interest in public affairs and society, as distinct from The Society, supplies a sufficient reason. It is much to be regretted that the two diaries do not overlap in time, Pepys's concluding three years before Hooke's starts, but it is amusing to note that the two men, of such different temperaments, met and liked one another. There are several references to Hooke in Pepys, the first speaking of "Mr. Hooke, who is the most, and promises the least, of any man in the world that ever I saw". Elsewhere we read :

"Discoursed with Mr. Hooke about the nature of sounds and he did make me understand the nature of musicall sounds made by strings, mighty prettily; and he told me that having come to a certain number of vibrations proper to make any tone, he is able to tell how many strokes a fly makes with her wings (those flies that hum in their flying) by the note that it answers to in musique, during their flying. That, I suppose, is a little too much refined; but his discourse in general of sound was mighty fine".

Thus the president-to-be (1684-86) of the Royal Society. On the other hand Hooke, in his briefer style, writes: "I was twise with Mr. Pepys who was very civil and kind", and even if he says later "Mr. Pepys master of the Trinity House made a long speech to no great purpose", it is only his way of stating that it was a "little too much refined".

What does the Diary tell us? We premise that it is obviously a truthful personal record, written without any thought of possible readers. Hooke sets down with a symbol every passage-and at one time they were frequent-with his mistress Nell Young and with her successors, and a host of pitiful details of his troubled health. Entries like 
"Drunk. Promised to pay whatever I signed to be paid" show that he spared himself no less than others in his directness. The first thing that stands out clearly is that Hooke was a sick man, trying all the time with medicine and diet to win a little ease. He was troubled constantly with what appears to have been a form of catarrh in his nose, with terrible headaches, with vomiting, with giddiness, with sleeplessness, with indigestion in various forms, and with fearful dreams-possibly also with worms, for he frequently took what he calls hagiox, which is probably hagiospermum, that is, santonin, which nowadays, at any rate, is only used for that trouble. Nevertheless, only occasionally was he too ill to work-"Ill all day, miserere mei deus". When anything agreed with him, or he slept, he thought it worth noting. "Eat nuts and brandy. Agreed well, and slept". "Slept well. Deo Gratias". The medicines which he took almost daily make a formidable list.*

There is some excuse, then, for Hooke's reputed ill-temper. Not only, however, was he without ease and sleep ; it is clear that he was prodigiously overworked. "The indefatigable Hooke", Weld may well call him. What is sometimes forgotten is that Hooke was a considerable architect, so much so that the College of Physicians in Warwick Lane has been attributed to Wren, although it appears that it was Hooke's. In any event, he was the architect for Bethlehem Hospital, to which very many entries refer, and he appears to have been responsible for the urn on the Monument, which gave some trouble. He designed private houses for many individuals mentioned in the Diary. He had been appointed City Surveyor in 1666, in which capacity he was assisting Sir Christopher Wren all through the period of the Diary, so that there is scarcely a page on which Sir Christopher is not mentioned. There are frequent records of his being with Sir Christopher and, incidentally, with Robert Boyle, Sir J. Hoskins, and other famous men, a circumstance to be noted in connexion with Thomas Molyneux's accusation that Hooke was "the most ill-natured, conceited man in the world, hated and despised by most of the Royal Society". Strange that he should afterwards have become secretary of the Society! The truth is probably that he was impatient with fools, and ill-tempered at times, especially when he thought himself slighted. As, however, he seems to have been on good terms with most of the first-class intellects of the time -Wren, Boyle, Ent, Glisson, Petty, Aubrey and a host of others - and throughout the Diary we find him playing chess with Haak, and in the company of Abraham Hill, Daniel Whistler,

\footnotetext{
* Sir D'Arcy Power, to whom I referred this passage, very kindly tells me that there is no doubt that Hooke's headaches were due to a chronic inflammation of his frontal sinuses.
}

Halley, and many others whose names occur over and over again as his coffee-house companions, he cannot have been so difficult as it pleased his enemies to make out. Sydenham invited Hooke to stay with him for six weeks.

If it is clear that Hooke was sharp-tempered, it is equally clear that in most cases he bore no malice. He discharged Nell Young from his service in 1673, but she continued to make his clothes and they visited one another, and although there was a quarrel in 1676, "Paid Nell for suit $6 \mathrm{~s} 8 \mathrm{~d}$ besides the full of her bill $16 \mathrm{~s} 6 \mathrm{~d}$ never more to do with her", within a few weeks we find "At Nell's", which thereafter occurs at intervals, as usual. Occasionally he rails at Tompion, who appears to have been slow and often behind his time, "a slug", "a rascall", but they continue to work together through the Diary, and no doubt knew one another's worth and idiosyncracies perfectly well. Even in the case of Oldenburg there is no unkind entry at his death, and Hevelius's fire is referred to sympathetically.

The people whom Hooke consistently stigmatises as rogues-Oldenburg ("a lying dog", "treacherous and a villain") and Sir John Cutler ("a villain", "a cheating knave", "Sir Stingy"I presume that this is Sir John) appear to have done much to earn his just indignation. Oldenburg first incurs censure for not registering things brought into the Society, and there are references to his not entering experiments long before the controversy over the application of the spiral spring to the balance wheel of watches. This dispute over the balance wheel seems to have upset Hooke more than any of his other troubles. We find the entry "Saw the Lying Dog Oldenburg's Transactions. Resolved to quit all employments and to seek my health". (Oldenburg was responsible for the Transactions, which were in a sense his property, as he received all profits on the sales.) It is often held that Hooke was in the wrong, and that Oldenburg was a harmless and devoted servant of the Society, as, indeed, he induced the Society to say. It is, however, recorded of him that he "had a peculiar temper, which prevented him agreeing well with others", while at the same time he had had an early training in diplomacy which possibly rendered his approach to the truth somewhat less direct than Hooke's.

When it is remembered that Oldenburg had a financial interest in Huygens' watch, since Huygens had assigned him the patent rights, and his petition for a patent is on record, it is, perhaps, possible to believe that he was not completely unprejudiced. His statement that none of Hooke's early watches had succeeded seems to go beyond what he could have known, and it was distinctly in his own interest to make it. Hooke's account of his early 
invention is true where we can check it, and it seems quite likely, in view of what we know, that he had, as he says, dropped the matter because of a very reasonable objection of his to a clause in the proposed agreement, to take it up again when he heard what Huygens had done. Thomas Thomson, in his "History of the Royal Society", refers to Hooke's character in the most censorious terms, and yet says in connexion with the balance spring, "Huygens has been considered as the author of this happy invention; but there is complete proof that Hooke anticipated him by about 14 years". Anyhow, Hooke's accusation that Oldenburg was "a traffiker in intelligence" seems absolutely justified. The Newton-Leibnitz controversy throws doubt on Oldenburg's discretion, and, in spite of his plaintive protests, when he was committed to the Tower, there are letters on record to show that he did meddle with political matters in them, as well as with scientific news. Sydenham, "universally recognised" according to the "Dictionary of National Biography", "as noble, modest and sincere" liked him as little as did Hooke, and I, for one, have the impression that he was an oblique, intriguing and toadying individual, jealous of Hooke's fame and earnings.

Sir John Cutler undoubtedly promised Hooke a yearly salary for lectures, which Hooke amply earned, and yet Sir John constantly evaded all attempts to make him pay it. He seems to have had a bad reputation. "Sir W. Petty" (a shrewd man if ever there was one) "told me that Sir J. Cutler would never pay me". Finally Hooke brought a Chancery suit against Sir John's heirs, in which he was successful. Waller quotes from a diary, no doubt the one in the British Museum, "In July 1696, being his Birth Day, his Chancery Suit for Sir John Cutler's salary, was determin'd for him, to his great satisfaction, which had made him very uneasy for several Years". It is not greatly to Hooke's discredit that he strongly resented this arrant attempt to bilk him, especially after his lectures had appeared in print with a handsome acknowledgment, in advance, of Sir John's bounty.

Another matter in which Hooke has incurred blame is the controversy with Hevelius about telescopic sights. Here there is no doubt that he was, objectively, in the right in every particular, and his estimate of the resolving power of the human eye, which he was the first to treat scienti. fically, is a very good one. All that he claims as advantages of telescopic sights has long since been established, and his defence against the strictures of Wallis and Molyneux is correct in manner and faultless in exposition and matter. What Waller says, that in his original "Animadversions", "he chanc'd to let slip some Expressions which, tho' possibly strictly true, could yet never be digested by Hevelius", is the most that can be urged against him. Hevelius, however, had slighted Hooke's original reasoned suggestion that he should use telescopic sights, so that a little warmth on Hooke's part is understandable. When the controversy was revived by Hevelius publishing "Annus Climactericus" in 1685, Hooke, at the Royal Society, "showed his experiments to prove the excellency of telescopic sights above plain ones, by comparing a direction by the eye with a radius of ten feet, with that of a telescope of eight inches ; and it appeared to the satisfaction of all present that there was a very great advantage in the telescope".

Let us see, however, if we can find any direct contradiction of the popular view of Hooke's character in the Diary. Among other faults with which we find him charged is "extreme parsimoniousness" (Weld). On the other hand, the Diary shows him spending freely. He is always buying books, often at prices round about $25 \mathrm{~s}$., a large sum in those days. His gifts to his niece Grace were generous : "This morning I gave Grace, Axes Stone Ring and speckled silk stockings and Ruby pendule" is but one of many entries. There are frequent records of small gifts to servants and messengers and of loans, which do not seem to have been repaid. He made extensive purchases of silks, and cloth, of wine and of brandy, and seems to have been always buying shoes. Incidentally, his use of the old term 'portoport' for port wine, of which he seems to have been fond, is much earlier than any given in the "New Oxford Dictionary". $\mathrm{He}$ frequented all the best taverns and coffee-houses and drank tea (the price of which was $15 s$. to $50 \mathrm{~s}$. a pound),* coffee and chocolate. He made gifts of tea and wine. One day he ate a pineapple "queen pine 2/.". He bought a hobby horse for Wren's son. He gave away copies of his books freely. These are only trifles, it may be said, but they are not rare. The general impression is that of a man who did not mind spending money on his friends and on himself-at the least the Diary makes it impossible to maintain that he was miserly.

Let us take another example. Baron Ernouf, author of the life of Denis Papin, says of his subject that he could not come to see Hooke, whom he terms "un de ces savants atrabilaires et soupçonneux dont l'espèce n'est pas perdue". Whether there was an occasion on which Hooke would not see Papin we cannot, of course, determine, but the Diary is full of entries of occasions on which he did, both when Papin visited him, and he visited Papin, so much so that under the name Papin in the index appears

*On January 16, 1679/80, Hooke "paid Chamberlain for tea, $25 \mathrm{sh}$ ".
A pound? A pound? 
Passim. In July 1679, for example, they met almost daily. He seems to have done his best for the unfortunate Frenchman: "I treated with Broom and Car for Pappin's book but they agreed not". The only disparagement, if it may be so called, anywhere set down, is "Pappin ungrateful". Incidentally, a younger brother of Papin's appears, who is new to me.

The interest of the Diary for the history of science is great. It is full of observations of importance, many of which, but not all, so far as I can trace, were published later. Hooke records the hollowness of the flame of a candle : the extinction of flame by "air generated by corrosion or fermentation", "and how saturated air did the same thing", as well as many other interesting experiments on combustion: how a glass can vibrate in four, six or eight segments as shown by the movement of water in it.* We find the record of his experiment with the falling bullet, but not of his letter to Newton on the subject, though some of his important letters to Newton are noted. A curious entry refers to "the way to make aparition on the Stage by a concave cylinder", evidently a very early form of 'Pepper's ghost', and another example of Hooke's extraordinary inventiveness. Another anticipation is his observation of the curious forms sometimes shown by the rising sun-"saw the sun rise very elliptical the under side much flatter than the upper", with a drawing, and, just a year later, "the sun rose very ovall, red and indented". The earliest observations on this subject quoted by Pernter in his "Meteorologische Optik" are considerably later, namely from an unpublished manuscript of the younger Cassini, who was born in 1667.

All this time, Hooke was polishing mirrors, seeing Tompion about watches, and making instruments. There are references to the scotoscope, of which Pepys mentions an example:

"There comes also Mr. Reeve with a microscope and scotoscope. For the first I did give him $£ 5-10$, a great price, but a most curious bauble it is, and he says, as good, nay, the best he knows in England, and he makes out the best in the world. The other he gives me, and is of value; and a curious curiosity it is to look objects in a dark room with."

and to the otheometer, which I cannot find mentioned elsewhere, but which is evidently a name given to one of the many forms of barometer which Hooke invented. A matter of biographical interest is that in two separate instances there are records of Hooke giving away in the autumn

\footnotetext{
"See Waller : "Life". Hooke noted that to each flgure corresponded "their particular and distinct Sounds or Notes", "the 4 and 8 were octaves and the 6 and 4 were fifths", observations which Tyndall assigns to Chladni.
}

copies of books which are dated the following year. There are also records of gilt copies, which must be very rare.

Reluctantly we must cease to quote from this book of manifold interests. One last note-for Mr. Dunne. On more than one occasion Hooke, who dreamt so much, speaks of prophetic dreams, as, for example, "Dreamt several things which came to pass the Day following", and again "Dream strangely fulfilled in Powis".

To produce this book has evidently been a labour of love for the editors, who have added an annotated list of the taverns and coffee-houses (some hundred and fifty of them !) mentioned by Hooke, and an excellent biographical index of getting on for two thousand names quoted in the Diary, nearly all of whom are Hooke's contemporaries. The transcription is, on the whole, excellent, but there are a few obvious errors, some of them amusing. "Eat candle, which agreed well" is not so surprising, if we suppose the word to have been "caudle"; and "cured by a felon in the neck" may well be a 'seton', if we remember the long esses.* "I wrote myopitius gunamen" is unlikely, if we remember that Hooke wrote a little tract called "myopibus juvamen". The "homocercle tadpoles in seed" are no doubt "homuncule", a term freely used for spermatozoa. Many of the authors and titles of foreign books and other foreign words have gone wrong: "Sutta anglicance" should clearly be "gutta anglicana": the "forces monantes" of Pardies' book should be "mouvantes" (possibly written "movantes" by Hooke) and I suspect that "Brooks' Mathematical Jewell" should be Blagrave's, for there is a book of this title by the latter author, of which a second version appeared in 1658 , but have never heard of one by Brooks. Chizzell, in the index, should be Chiswell, who published most of the "Philosophical Collections". Slips like these, and others not quoted, are probably inevitable in a work of this length, and a few of them give the reader pleasant exercise in tracking them down. A word of praise must be spoken for the admirable illustrations, especially those of buildings planned by Hooke.

The publication of this Diary in a worthy form is an event for the history of science, and we hope that the encouragement shown by the Royal Society to its learned librarian, Mr. H. W. Robinson, upon whom the labour of the work has chiefly fallen, will incite him to further researches into the early history of the Society.

\section{E. N. DA C. Andrade.}

\footnotetext{
* Felon was, of course, used as a term for a sore, Cf. Herrick.

"Where others love and praise my verses, still Thy long black thumbnail marks them out for ill, A fellon take it, or some whitflaw come

For to unslate or to untile that thumb".
}

Nevertheless, a deliberately produced felon is unlikely. 